\title{
Purification of plant-derived anti-virus mAb through optimized pH conditions for coupling between protein A and epoxy- activated beads
}

\author{
Ilchan Song Equal first author, 1 , Yang Joo Kang Equal first author, 1 ， Su-Lim Choi ${ }^{2}$ ， Dalmuri Han ${ }^{3}$ ， Deuk-Su Kim ${ }^{1}$, Hae \\ Kyung Lee ${ }^{3}$, Joon-Chul Lee ${ }^{4}$, Jeanho Park ${ }^{4}$, Do-Sun Kim ${ }^{5}$, Kisung Ko ${ }^{\text {Corresp. } 1}$ \\ 1 Department of Medicine, College of Medicine, Chung-Ang University, Seoul, South Korea \\ 2 Protein Purification Laboratory, Biotech R\&D center, Amicogen, Jinju, South Korea \\ 3 Division of Bacterial Disease Research, Korea Centers for Disease Control and Prevention, Osong, South Korea \\ 4 Research Institute of Industrial Technology Convergence, Korea Institute of Industrial Technology, Ansan, South Korea \\ ${ }^{5}$ Vegetable Research Division, National Institute of Horticultural and Herbal Science, Rural Development Administration, Wanju-gun, South Korea \\ Corresponding Author: Kisung Ko \\ Email address: ksko@cau.ac.kr
}

The main goal of this research was to determine optimum pH conditions for coupling between protein A and epoxy-activated Sepharose beads for purification of monoclonal antibodies (mAbs) expressed in plants. To confirm the effect of $\mathrm{pH}$ conditions on purification efficacy, epoxy-activated agarose beads were coupled to protein $A$ under the $\mathrm{pH}$ conditions of $8.5,9.5,10.5$, and 11.5 (8.5R, 9.5R, 10.5R, and 11.5R, respectively). Three hundred grams of fresh leaf tissue of transgenic Arabidopsis expressing human antirabies $\mathrm{mAb}\left(\mathrm{mAb} \mathrm{b}^{\mathrm{p}}\right) \mathrm{SO} 57$ were harvested to isolate the total soluble protein (TSP). An equal amount of TSP solution was applied to five resin groups including commercial protein $A$ resin (GR) as a positive control. The modified $8.5 R, 9.5 R, 10.5 R$, and $11.5 R$ showed delayed elution timing compared to the GR control resin. Nano-drop analysis showed that the total amount of purified mAbPO57 mAbs from $60 \mathrm{~g}$ of fresh leaf mass were not significantly different among 8.5R $(400 \mu \mathrm{g}), 9.5 \mathrm{R}(360 \mu \mathrm{g}), 10.5 \mathrm{R}(380 \mu \mathrm{g})$, and $\mathrm{GR}(350 \mu \mathrm{g})$. The 11.5R $(25 \mu \mathrm{g})$ had the least mAbPSO57. SDS-PAGE analysis showed that the purity of mAbPO57 was not significantly different among the five groups. Rapid fluorescent focus inhibition

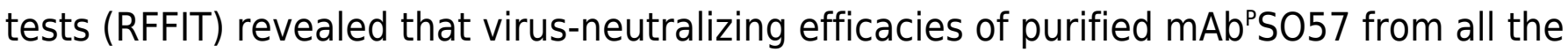
five different resins including the positive control resin were similar. Taken together, both $\mathrm{pH} 8.5$ and 10.5 coupling conditions with high recovery rate should be optimized for purification of $\mathrm{mAb}$ PO 57 from transgenic Arabidopsis plant, which will eventually reduce down-stream cost required for mAb production using the plant system. 
1 Purification of plant-derived anti-virus mAb through optimized pH

conditions for coupling between protein A and epoxy-activated

\section{beads}

Ilchan Song ${ }^{1 \dagger}$, Yang Joo Kang ${ }^{1 \dagger}$, Su-Lim Choi ${ }^{2}$, Dalmuri Han ${ }^{3}$, Deuk-Su Kim ${ }^{1}$, Hae Kyung Lee ${ }^{3}$, Joon-Chul Lee ${ }^{4}$ Jeanho Park', Do-Sun Kim ${ }^{5}$ Kisung Ko ${ }^{{ }^{*}}$

${ }^{1}$ Department of Medicine, College of Medicine, Chung-Ang University, Seoul, Korea

2 Protein Purification Laboratory, Biotech R\&D center, Amicogen, Inc., Jinju, Korea

${ }^{3}$ Division of Bacterial Disease Research, Korea Centers for Disease Control and Prevention, Osong, Korea

${ }^{4}$ Research Institute of Industrial Technology Convergence, Korea Institute of Industrial Technology, Ansan, Korea

${ }^{5}$ Vegetable Research Division, National Institute of Horticultural and Herbal Science, Rural Development Administration, Wanju-gun, South Korea

$\dagger$ These authors contributed equally to this work.

* Corresponding author: Kisung $\mathrm{Ko}^{1}$

Email address: ksko@cau.ac.kr

Keywords: Antibody; Epoxy-activated beads; $\mathrm{pH}$ condition; Protein A; Purification

\section{Abstract}

The main goal of this research was to determine optimum $\mathrm{pH}$ conditions for coupling between protein A and epoxy-activated Sepharose beads for purification of monoclonal antibodies (mAbs) expressed in plants. To confirm the effect of $\mathrm{pH}$ conditions on purification efficacy, epoxyactivated agarose beads were coupled to protein $\mathrm{A}$ under the $\mathrm{pH}$ conditions of $8.5,9.5,10.5$, and $11.5(8.5 \mathrm{R}, 9.5 \mathrm{R}, 10.5 \mathrm{R}$, and 11.5R, respectively). Three hundred grams of fresh leaf tissue of transgenic Arabidopsis expressing human anti-rabies $\mathrm{mAb}\left(\mathrm{mAb}^{\mathrm{P}}\right) \mathrm{SO} 57$ were harvested to isolate the total soluble protein (TSP). An equal amount of TSP solution was applied to five resin groups including commercial protein A resin (GR) as a positive control. The modified 8.5R, 9.5R, 10.5R, 
and 11.5R showed delayed elution timing compared to the GR control resin. Nano-drop analysis showed that the total amount of purified mAbPSO57 mAbs from $60 \mathrm{~g}$ of fresh leaf mass were not significantly different among 8.5R (400 $\mu \mathrm{g}), 9.5 \mathrm{R}(360 \mu \mathrm{g}), 10.5 \mathrm{R}(380 \mu \mathrm{g})$, and GR (350 $\mu \mathrm{g})$. The 11.5R (25 $\mu \mathrm{g})$ had the least $\mathrm{mAb}{ }^{\mathrm{P} S O 57 .}$ SDS-PAGE analysis showed that the purity of $\mathrm{mAb} \mathrm{P}^{\mathrm{P} O 57}$ was not significantly different among the five groups. Rapid fluorescent focus inhibition tests (RFFIT) revealed that virus-neutralizing efficacies of purified $\mathrm{mAb} \mathrm{b}^{\mathrm{PSO}} 5$ from all the five different resins including the positive control resin were similar. Taken together, both $\mathrm{pH} 8.5$ and 10.5 coupling conditions with high recovery rate should be optimized for purification of mAbPSO57 from transgenic Arabidopsis plant, which will eventually reduce down-stream cost required for $\mathrm{mAb}$ production using the plant system.

\section{Introduction}

Plants have enormous potential as bioreactors for the large-scale production of therapeutic reagents such as recombinant vaccines and antibodies (Kang et al. 2017; Kim et al. 2016; Lim et al. 2014). One of the major factors limiting commercial advances in plant-derived pharmaceuticals is the high cost and inefficiency of purification (Hussack et al. 2010; Tschofen et al. 2016). Plant leaf extracts contain an array of indigenous proteins and other water-soluble cell components such as DNA, chlorophyll and other pigments, alkaloids, phenolics, polysaccharides, and proteases (Wilken \& Nikolov 2012; Zhang et al. 2015). These components can affect the quality and yield of final purified protein or reduce purification efficiency because of resin or membrane fouling (Jha et al. 2016; Moussavou et al. 2015). Thus, extraction conditions should be optimized through screening and evaluation of the tissue disruption technique, particle size distribution, buffer composition, plant tissue-to-buffer ratio, and subcellular compartment expression (Park et al. 2015; Romanik et al. 2007).

Staphylococcal protein A (SPA) is one of the first discovered immunoglobulin-binding molecules and has been extensively studied during the past decades. Because of its affinity to immunoglobulins, protein A has been widely used as a tool in the detection and purification of antibodies, and its role has been further developed in one of the most commonly employed affinity purification systems (Hober et al. 2007; Liu et al. 2010; Mazzer et al. 2015). However, protein A should be properly coupled to a matrix such as agarose beads, as the orientation of protein A when coupled to the bead affects the holding capacity of the mAb and hence can affect purification 
efficiency (Groher \& Suess 2016; Welch et al. 2017; Zhang et al. 2017). Sulfhydryl groups are the most highly reactive nucleophiles with epoxides, requiring a buffered system in the range of $\mathrm{pH}$ 7.5-8.5 for efficient coupling (Hermanson 2013; Tehrani Najafian et al. 2017). Amine nucleophiles react at moderate alkaline $\mathrm{pH}$ values, typically needing buffer environments of at least $\mathrm{pH}$ 9.0. The reaction of the epoxide functionalities with hydroxyls requires high $\mathrm{pH}$ conditions, usually in the range of $\mathrm{pH} 11-12$. In this study, four different $\mathrm{pH}$ conditions $(\mathrm{pH} 8.5$, 9.5, 10.5, and 11.5) were applied to manufacture epoxy-activated beads coupled to protein A. Research to develop protein A affinity chromatography for efficient purification of biotherapeutic proteins from plant biomass as a bioreactor has not yet been undertaken. The main goal of the present research was to determine coupling $\mathrm{pH}$ conditions between protein A and epoxy-activated agarose beads that could efficiently purify anti-rabies mAbs derived from transgenic Arabidopsis plants. The purified plant-derived $\mathrm{mAbs}\left(\mathrm{mAb}^{\mathrm{P}} \mathrm{s}\right)$ from four different resins and a commercially available protein A agarose resin as a positive control were compared for purification efficiency, purity, and neutralizing activity.

\section{Material and Methods}

\subsection{Floral dip transformation}

Plant expression vector $\mathrm{pBI} \mathrm{mAb} 57$ carrying anti-rabies virus $\mathrm{mAb} \mathrm{LC}$ and $\mathrm{HC}$ fused to $\mathrm{KDEL}$ ER retention signal was transferred into Agrobacterium tumefaciens strain GV3101::pMP90 by electroporation (Fig. 1a). A tumefaciens carrying mAb ${ }^{\mathrm{P} S O} 57$ expression cassettes was cultured at $28-30^{\circ} \mathrm{C}$ in LB with kanamycin for two days. Agrobacteria were centrifuged (4,000 rpm, $\left.10 \mathrm{~min}\right)$, and the pellets were resuspended with infiltration media $\left(4.3 \mathrm{~g} \cdot \mathrm{L}^{-1}\right.$ of MS salts, $30 \mathrm{~g} \cdot \mathrm{L}^{-1}$ of sucrose, $0.1 \mathrm{~g} \cdot \mathrm{L}^{-1}$ of myo-inositol). Wild type Col-0 Arabidopsis plants were transformed using the floral dip method (Clough \& Bent 1998). Col-0 Arabidopsis seeds were sown on soil, and seedlings were grown for four weeks for floral dip transformation under standard conditions $(16 \mathrm{~h} \mathrm{light} / 8 \mathrm{~h}$ dark cycle, $22^{\circ} \mathrm{C}$ ) in a growth chamber. To induce proliferation of many secondary bolts, first bolts of Arabidopsis were trimmed off. The plant pots were inverted into the infiltration solution containing $0.02 \%$ Silwet L-77 for 5 min at a time, and the infiltrated plants were covered with black plastic bags for two days to ensure high humidity. On the following day, the plastic bags were removed, 
92 and the plants were maintained in the standard conditions in a growth chamber until seeds were well ripened. Then, the obtained seeds were sown on agar plates containing Murashige and Skoog (MS) medium (pH 5.7) $\left[10 \mathrm{~g} \cdot \mathrm{L}^{-1}\right.$ of sucrose, $8 \mathrm{~g} \cdot \mathrm{L}^{-1}$ of plant agar, and $4.3 \mathrm{~g} \cdot \mathrm{L}^{-1}$ of MS B5 vitamin (Duchefa Biochemie, Haarlem, Netherlands)], containing $50 \mathrm{mg} \cdot \mathrm{L}^{-1} \mathrm{kanamycin}$ and $25 \mathrm{mg} \cdot \mathrm{L}^{-1}$ cefotaxime to select true leaf generating shoots. For a further study, all shoots with green leaves were transplanted to a soil pot and maintained in a growth chamber at $22^{\circ} \mathrm{C}$ under a $16 \mathrm{~h}$ light $/ 8 \mathrm{~h}$ dark cycle.

\subsection{Genomic DNA preparation and PCR analysis}

Plant genomic DNA preparation and PCR analysis were conducted as described in Song et al (2015). Genomic DNA was isolated from the rosette leaves of Arabidopsis plants using a DNA extraction kit (RBC Bioscience, Seoul, Korea), according to the manufacturer's recommendations. Polymerase chain reaction (PCR) analysis was performed to confirm the presence of heavy chain (HC) (281 bp) and light chain (LC) (227 bp) genes of $\mathrm{T}_{1}$ plants. Primer sets were described as follows: HC forward primer, 5'-CAG ACT CAC CAT TAC CGC-3'; HC reverse primer, 5'-AGT AGT CCT TGA CCA GGC-3'; LC forward primer, 5'-CAC TGG AAC CAG CAG TGA-3'; LC reverse primer, 5'-TGT AGT CGC CTG CAT ATG A-3'. The PCR reaction was subjected to 26 cycles of $94^{\circ} \mathrm{C}$ for $20 \mathrm{~s}, 58^{\circ} \mathrm{C}$ for $10 \mathrm{~s}$, and $72^{\circ} \mathrm{C}$ for $30 \mathrm{~s}$. The PCR products were analyzed by electrophoresis in a 1.0\% agarose gel with ethidium bromide, and visualized under UV illumination. The $\mathrm{pBI}$ mAb 57 vector was used as a positive control, and genomic DNA extracted from Col-0 Arabidopsis was used as a negative control.

\subsection{Western blot analysis}

Western blot analysis was conducted as previously described in Lu Z et al (2012). To confirm protein expression levels of transgenic Arabidopsis, $80 \mathrm{mg}$ of fresh leaf tissue, which had previously been confirmed as having the target mAbPSO57 protein genes [mAb SO57 HC (281 bp), LC (227 bp)] by PCR, was ground in $300 \mu \mathrm{L}$ of $1 \mathrm{X}$ PBS buffer (137 mM NaCl, $2.7 \mathrm{mM} \mathrm{KCl}$, $10 \mathrm{mM} \mathrm{Na}_{2} \mathrm{HPO}_{4}, 2 \mathrm{mM} \mathrm{KH} \mathrm{PO}_{4}, \mathrm{pH}$ 7.4). Homogenates were boiled with sample buffer (1 M Tris-HCl, 50\% glycerol, 10\% SDS, 5\% 2-mercaptoethanol, $0.1 \%$ bromophenol blue) and cooled in ice. After centrifugation for $5 \mathrm{~min}$ at $10,200 \times g, 20 \mu \mathrm{L}$ of supernatant was loaded in $12.5 \%$ SDS-PAGE gel and transferred to a nitrocellulose membrane (Millipore, Billerica, MA). The 
123 membrane was then blocked with 5\% skim milk (Sigma, St. Louis, MO) in 1X PBS-T (1X PBS

124 plus $0.1 \%[\mathrm{v} / \mathrm{v}]$ Tween 20 ) for $2 \mathrm{~h}$ at $25^{\circ} \mathrm{C}$. After blocking treatment, the blots were incubated with

125 peroxidase-conjugated goat anti-human IgG Fc $\gamma$ (Product \# 109-035-008, Jackson Immuno

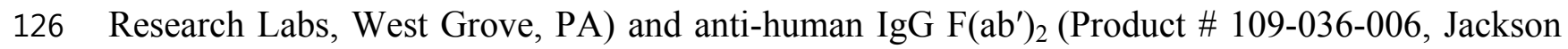

127 Immuno Research Labs, West Grove, PA), which recognize the HC and LC of mAb ${ }^{\mathrm{P} S}$ 57,

128 respectively. Protein bands were detected with the SuperSignal West Pico Chemiluminescent

129 Substrate (Thermo Scientific, Rockford, IL) and visualized using X-ray films (Fuji, Tokyo, Japan).

130 The leaf of Col-0 Arabidopsis was used as a negative control.

131

132

\subsection{Purification of $\mathrm{mAb}{ }^{\mathrm{P} S O 57}$ from plant leaf using different resins}

133

134

For the purification of the plant-derived anti-rabies mAbPSO57, $350 \mathrm{~g}$ of Arabidopsis leaf tissue was homogenized in a HR2094 blender (Philips, Seoul, Korea) using extraction buffer (37.5 $\mathrm{mM}$ Tris- $\mathrm{HCl}, \mathrm{pH} 7.5 ; 50 \mathrm{mM} \mathrm{NaCl} ; 15 \mathrm{mM}$ EDTA; $75 \mathrm{mM}$ sodium citrate; $0.2 \%$ sodium thiosulfate) as previously described in Park et al (2015) (Fig. 2). Ground samples were centrifuged at $9,000 \times \mathrm{g}$ for $30 \mathrm{~min}$ at $4^{\circ} \mathrm{C}$, then the supernatant was filtered through a Miracloth (Biosciences, La Jolla, CA), and the $\mathrm{pH}$ of the filtrate was reduced to 5.1 by adding acetic acid ( $\mathrm{pH} 2.4$ ). The solution was centrifuged to remove chlorophyll at $10,200 \times \mathrm{g}$ for $30 \mathrm{~min}$ at $4^{\circ} \mathrm{C}$. The $\mathrm{pH}$ of the solution was then increased to 7.0 by adding $3 \mathrm{M}$ Tris- $\mathrm{HCl}$, and $15 \%$ ammonium sulfate was added to the solution at $4{ }^{\circ} \mathrm{C}$. After centrifugation at $9,000 \times \mathrm{g}$ for $30 \mathrm{~min}$ at $4{ }^{\circ} \mathrm{C}, 45 \%$ of ammonium sulfate was added to the collected supernatant at $4^{\circ} \mathrm{C}$. After overnight incubation, the total solution was centrifuged at $10,200 \times \mathrm{g}$ for $30 \mathrm{~min}$ at $4^{\circ} \mathrm{C}$. The pellet was resuspended in an extraction buffer with $1 / 12$ volume of the original extraction buffer, and centrifuged at $10,200 \times \mathrm{g}$ for $30 \mathrm{~min}$ at $4^{\circ} \mathrm{C}$. Final solutions were divided into five groups, and each solution was applied to four different resins and a control GE protein A resin for purification of $\mathrm{mAb}$ PSO57 from TSP solution (Fig. 2). Four resins were manufactured by using Sepharose 4 Fast Flow (GE Healthcare, Uppsala, Sweden). The Sepharose resin was washed on a filter funnel with distilled water and activated with 1,4butanediol diglycidyl ether in $0.6 \mathrm{M} \mathrm{NaOH}$ solution for $10 \mathrm{~h}$ at $25^{\circ} \mathrm{C}$. After washing, the activated resin was coupled with purified recombinant protein A $(10 \mathrm{mg} / \mathrm{ml}$ resin) in a coupling buffer (100 $\mathrm{mM}$ Na-phosphate, $1 \mathrm{mM}$ EDTA, $\mathrm{pH} 8.5, \mathrm{pH} 9.5, \mathrm{pH} 10.5$, and $\mathrm{pH} 11.5$ ) for $18 \mathrm{~h}$ at $37^{\circ} \mathrm{C}$. Each several times and then deactivated with $1 \mathrm{M}$ ethanolamine $\mathrm{pH}$ 8.0. 


\subsection{Protein concentration analysis}

156 Eluted fraction F1 F7 of purified $\mathrm{mAb}^{\mathrm{p} S O} 57$ were quantified using Epoch spectrometer (UV-Vis

157 Microplate Spectrophotometer, Biotech, Winooski, VT) (Oey et al. 2009; Song et al. 2015).

158 Aliquots of $2 \mu \mathrm{L}$ samples were pipetted directly onto the pedestal and measured at $206 \mathrm{~nm}$ to 280

$159 \mathrm{~nm}$. The concentrations of purified $\mathrm{mAb} \mathrm{p}^{\mathrm{p} S} 57$ at eluted fraction $\mathrm{F} 1 \sim \mathrm{F} 7$ were calculated from the 160 absorbance values by Gen5 2.01 software (Biotek, Highland Park, VT).

161

162

163

164

165

166

167

168

169

170

171

172

173

174

175

176

177

178

179 180

181

182

183

\subsection{In vitro rabies virus neutralization assay}

To compare neutralizing activities of purified $\mathrm{mAb}^{\mathrm{P}} \mathrm{s}$ obtained from different resins $(8.5 \mathrm{R}$, 9.5R, and 10.5R), rapid fluorescent focus inhibition test (RFFIT) was performed plant-derived $\mathrm{mAb}^{\mathrm{p}} \mathrm{s}(8.5 \mathrm{R}, 9.5 \mathrm{R}$, and 10.5R) and anti-rabies immunoglobulin [National Institute for Biological Standards and Control (NIBSC), Potters Bar, UK], respectively. The mAbs, at an initial concentration of $20 \mu \mathrm{g} / \mathrm{ml}$, were diluted in 1:2.5, 1:12.5, 1:62.5, and 1:312.5 with advanced Dulbecco's modified Eagle's medium (Sigma, St. Louis, MO). A $100 \mu \mathrm{L}$ aliquot of each diluted sample and $100 \mu \mathrm{L}$ of Challenge Virus Standard (CVS-11) containing 32-100 FFD 50 were mixed in an 8-well chamber slide (Nunc, Rochester, NY), performed in duplicate. These mixed samples were incubated in a $5 \% \mathrm{CO}_{2}$ incubator at $35^{\circ} \mathrm{C}$ for $90 \mathrm{~min}$. After incubation, $0.5 \times 10^{5}$ cells of mouse neuroblastoma (N2a) cells with $100 \mu \mathrm{L}$ total volume were added to each chamber and incubated at $35^{\circ} \mathrm{C}$ in a $5 \% \mathrm{CO}_{2}$ incubator for $20 \mathrm{~h}$. After incubation, the supernatant was removed, and monolayers were fixed in $80 \%$ acetone for $10 \mathrm{~min}$ at $23^{\circ} \mathrm{C}$ after washing with $1 \mathrm{X}$ PBS. The slides were stained with 0.0025\% Evans Blue solution (ScienceLab, Houston, TX), containing anti-rabies virus monoclonal antibodies conjugated to Alexa Fluor ${ }^{\mathrm{TM}} 488$ (Invitrogen, Carlsbad, $\mathrm{CA}$ ), and incubated at $37^{\circ} \mathrm{C}$ for $30 \mathrm{~min}$. After incubation, the slides were washed 3 times for $1 \mathrm{~min}$ with $1 \mathrm{X}$ PBS and then coverslips were mounted on each chamber slide. The slides were observed under a fluorescence microscope (Carl Zeiss, Oberkochen, Germany) (200X magnification).

\section{Results}

3.1. Generation of Arabidopsis transformants expressing anti-rabies virus mAbPSO57 
184

185

186

187

188

189

190

191

192

193

194

195

196

197

198

199

200

201

202

203

204

205

206

207

208

209

210

211

212

Two thousand $\mathrm{T}_{1}$ seeds obtained after floral dip transformation were plated on MS medium containing kanamycin $(50 \mathrm{mg} / \mathrm{L})$ for selection of transformants. Of these seeds, 40 plants had true leaves with green color, whereas almost all the sown seeds failed to develop true leaves and were etiolated with light yellow shoots. Forty transformants with true leaves survived from kanamycin media, and were transplanted to a growth chamber in standard conditions (Fig. 1b). The rosette leaves of the 40 plants were used as material for the confirmation of transgene insertion. The expected PCR HC and LC gene bands were observed in all $\mathrm{T}_{1}$ Arabidopsis plants (Fig. 1b). No PCR band was observed in wild type Col-0 Arabidopsis (data not shown). Repeated kanamycin selections were conducted in successive generations to find homozygous seeds for mass production of transgenic Arabidopsis plants expressing mAbPSO57 (Fig. 1c).

\subsection{Expression of heavy chain and light chain proteins in transgenic} Arabidopsis

After confirmation of transgene insertion, expression of $\mathrm{HC}$ and LC proteins in leaves was investigated by western blot analysis (Fig 1b). The HC and LC protein bands were detected approximately at $50 \mathrm{kDa}$ and $25 \mathrm{kDa}$, respectively. Among the 40 plants, 26 plants showed $\mathrm{HC}$ and LC protein bands (data not shown), and four plants (a-2, b-2, b-3, and b-4) showed high protein expression levels (Fig 1b). $\mathrm{T}_{2}$ seeds from the b-2 plant with high protein expression levels were obtained for further study.

\subsection{Purification of human anti-rabies mAb from Arabidopsis leaf tissue under different $\mathrm{pH}$ conditions}

Different agarose resins coupled to protein A under $\mathrm{pH}$ 8.5, 9.5, 10.5, and 11.5 conditions were used to purify the anti-rabies mAbs from plant leaf biomass. Two steps were used, which were ammonium sulfate-mediated TSP precipitation, followed by protein A affinity chromatography (Fig. 2). These steps efficiently isolated the majority of TSP including rubisco protein and separated specific mAbs from plant leaf extracts. SDS-PAGE analysis was used to identify the HC $(50 \mathrm{kDa})$ and $\mathrm{LC}(25 \mathrm{kDa})$ of the anti-rabies virus $\mathrm{mAb}{ }^{\mathrm{P} S O} 57$ from elution fractions from plant

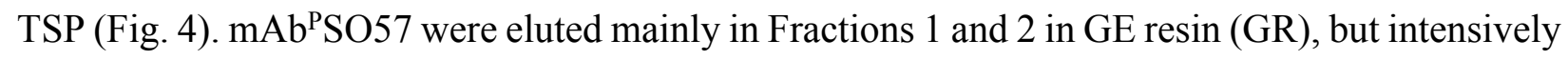


213 eluted in Fraction 4 in other resins [pH 8.5 (8.5R), 9.5 (9.5R), 10.5 (10.5R), and 11.5 (11.5R)] 214 (Fig. 4).

215

216

\subsection{Quantification of purified $\mathrm{mAb} \mathrm{b}^{\mathrm{PSO}} \mathrm{S} 7$}

217

218

219

220

221

222

223

224

225

226

227

228

229

230

231

232

233

234

235

236

237

238

239

240

241

242

Each eluted sample (F1-F7) was quantified using a protein concentration analysis (UV-Vis Microplate Spectrophotometer, BioTek, Winooski, VT). The highest concentration of mAbP SO57 among seven fractions (F1-F7) of each experimental group were as follows: GR (F2, $310.5 \mu \mathrm{g} / \mathrm{ml})$, 8.5R (F4, $485 \mu \mathrm{g} / \mathrm{ml}), 9.5 \mathrm{R}(\mathrm{F} 4,550 \mu \mathrm{g} / \mathrm{ml}), 10.5 \mathrm{R}(\mathrm{F} 4,410 \mu \mathrm{g} / \mathrm{ml})$, and 11.5R (F4, $15 \mu \mathrm{g} / \mathrm{ml})$, respectively (Fig. 5). The total amount of obtained mAbs were $350 \mu \mathrm{g}$ (GR), $400 \mu \mathrm{g}(8.5 \mathrm{R}), 360$ $\mu \mathrm{g}$ (9.5R), $380 \mu \mathrm{g}$ (10.5R), and $25 \mu \mathrm{g}$ (11.5R), respectively (data not shown). 8.5R resins had the highest amount of purified $\mathrm{mAb}{ }^{\mathrm{P} S O} 57$ in the other fractions compared to the other groups.

\subsection{Neutralizing activity of the purified $\mathrm{mAb} \mathrm{b}^{\mathrm{P} S O 57}$}

The rabies virus-neutralizing activities of $\mathrm{mAb}{ }^{\mathrm{P} S O} 57$ purified from different resins were compared to commercial antibodies (Anti-rabies human immunoglobulin). The mean RFFIT values of each group were as follows: GR (7.16 IU/ml), 8.5R (5.50 IU/ml), 9.5R (7.29 IU/ml), and 10.5R (8.29 IU/ml), respectively. The $\mathrm{mAb} \mathrm{b}^{\mathrm{P}}$ could not be purified from $11.5 \mathrm{R}$ resin (Fig. 6 ). Thus, 11.5R was omitted for this neutralization assay.

\section{Discussion}

Protein affinity purification was widely used to purify biopharmaceutical proteins based on specific surface interactions, efficiently separating biological molecules with target antibodies and immobilized protein ligands (Kubota et al. 2017; Saraswat et al. 2013; Sheng \& Kong 2012). In affinity chromatography, protein A as a ligand covalently bonded to an agarose matrix is used to separate a target protein from a protein pool including cell lysate. The agarose matrix should be activated for covalent binding of ligands such as protein A for affinity purification. The agarose resin is epoxide-activated by immobilization of oxiranes such as 1,4-butanediol diglycidyl ether onto the matrix (Oliveira et al. 2015; Zucca et al. 2016).

The epoxide groups can be coupled with thiols, primary amines, and hydroxyl HOOC-groups depending on $\mathrm{pH} 8.5,9.5,10.5$, and 11.5 conditions, respectively. The immobilized ligand such as 
243 protein A on an epoxy-activated agarose matrix can bind to monoclonal antibodies (Mazzer et al. 244 2015; Minakuchi et al. 2013). The directionality of Protein A attached to resin is different 245 depending on the immobilized residue. When protein $\mathrm{A}$ is immobilized on the resin with amine $246\left(\mathrm{NH}_{2}^{-}\right)$and hydroxyl $\left(\mathrm{OH}^{-}\right)$groups, the outward directionality of Protein $\mathrm{A}$ is random. Thus, we 247 optimized the cysteine residue at the $\mathrm{C}$ terminal of protein A to give a constant directionality. 248 When the protein A binds to the sulfhydryl group $\left(\mathrm{SH}^{-}\right)$, it is directed outward in a row. It is 249 expected that the constant directionality can deliberately induce protein A to become saturated 250 with the resin by using a large amount of protein A and reacting for a long time. In this research, 251 we manufactured four differently coupled the optimized protein A and epoxy-activated agarose 252 resins to purify plant derived anti-rabies monoclonal antibodies under different $\mathrm{pH}$ conditions. 253 SDS-PAGE results showed that the capacity of $\mathrm{pH} 11.5$ group was too low to effectively purify $254 \mathrm{mAb}$ PSO57 in transgenic Arabidopsis compared to that in the other experimental groups ( $\mathrm{pH} 8.5$, 255 9.5, and 10.5) including protein A Sepharose ${ }^{\mathrm{TM}}$ resin (GE Healthcare, Uppsala, Sweden). Groher 256 and Suess (Groher \& Suess 2016) speculated that the binding power of the hydroxyl groups and 257 258 epoxy-activated agarose beads in $\mathrm{pH} 11.5$ conditions is weakened by the hindrance of hydroxyl groups on the surface of the agarose beads. Epoxy-activated agarose coupled with protein A resin under $\mathrm{pH}$ conditions greater than 13 was not recommended for purification of monoclonal antibodies (Sada, 1990). SDS-PAGE results showed that the four different $\mathrm{pH}$ conditions had longer retention time (intensively eluted from Fraction 4) than GE resin (intensively eluted from Fraction 1). We hypothesize that these retention time differences are due to epoxy-activated beads' structure and bead porosity. Indeed, the pore sizes of the four differently coupled resins with protein A were similar to that of the GE resin. It is speculated that under $\mathrm{pH} 8.5$ conditions, the lower level of sulfhydryl residue of protein A compared to the amine residue induced holding the protein $\mathrm{A}$ in a specific orientation on the resin rather than in random directions (Zhang et al. 2017), consequently enhancing the mAb binding capacity (Batalla et al. 2012; Liu \& Yu 2016). However, SDS-PAGE results showed that the effect of $\mathrm{pH}$ conditions on coupling with epoxy beads did not affect the purity of plant-derived $\mathrm{mAb}{ }^{\mathrm{P} S O} 57$. Although the $8.5 \mathrm{R}, 9.5 \mathrm{R}$ and $10.5 \mathrm{R}$ showed some non-specific bands below $50 \mathrm{kDa}$, the purified quantity are more than two times stronger than the GE. The virus-neutralizing efficacies of four $\mathrm{mAb}{ }^{\mathrm{P} S O} 57$ purified from different resins (GE, $\mathrm{pH}$ 8.5, $\mathrm{pH}$ 9.5, $\mathrm{pH}$ 10.5) were approximately three times higher than that of anti-rabies human immunoglobulin. Among the purified plant-derived antibodies samples, purified sample with the 
27410.5 resin showed the highest RFFIT value, indicating that the 10.5 resin purified more active mAb

275 form compared to the others.

276

\section{5. Conclusion}

In this study, the effect of $\mathrm{pH}$ on coupling between protein $\mathrm{A}$ and epoxy-activated beads was investigated with transgenic Arabidopsis expressing mAbPSO57. Overall, our results suggest that Arabidopsis plant leaf. This is the first research report on optimization of protein A chromatograph resin using manipulation of coupling with $\mathrm{pH}$ conditions. Plant expression system has emerged as one of the most promising platforms for the large-scale production of therapeutic reagents (Sharma \& Sathishkumar 2017). Several major companies have occupied the most proportion for the commercial resin market (Pollock et al. 2017). In addition, the cost of commercialized affinity resin product is relatively high (Buyel et al. 2017). The currently described resin, in this study, was confirmed to have equivalent qualities compared to commercially available protein A resin. For a commercial use of plant as a bioreactor, resin cost which occupies a large portion of down-stream cost should be reduced in the future (Arora et al. 2017). By using our currently described cost effective resins, thus, bulk production of therapeutic mAbs using plant system would be realized in the future.

\section{References}

Arcalis E, Marcel S, Altmann F, Kolarich D, Drakakaki G, Fischer R, Christou P, and Stoger E. 2004. Unexpected deposition patterns of recombinant proteins in post-endoplasmic reticulum compartments of wheat endosperm. Plant Physiology 136:3457-3466. DOI: 10.1104/pp.104.050153

Arora S, Saxena V, and Ayyar BV. 2017. Affinity chromatography: A versatile technique for antibody purification. Methods 116:84-94. DOI: 10.1016/j.ymeth.2016.12.010

Batalla P, Bolívar JM, Lopez-Gallego F, and Guisan JM. 2012. Oriented covalent immobilization of antibodies onto heterofunctional agarose supports: A highly efficient immuno-affinity chromatography platform. Journal of Chromatography A 1262:56-63. DOI: 10.1016/j.chroma.2012.08.058 
304

305

306

307

308

309

310

311

312

313

314

315

316

317

318

319

320

321

322

323

324

325

326

327

328

329

330

331

332

333

334

Buyel J, Twyman R, and Fischer R. 2017. Very-large-scale production of antibodies in plants: The biologization of manufacturing. Biotechnology advances 35:458-465. DOI: 10.1016/j.biotechadv.2017.03.011

Clough SJ, and Bent AF. 1998. Floral dip: a simplified method for Agrobacterium-mediated transformation of Arabidopsis thaliana. The plant journal 16:735-743.

Groher F, and Suess B. 2016. In vitro selection of antibiotic-binding aptamers. Methods 106:4250. DOI: $10.1016 /$ j.ymeth.2016.05.008

Hermanson GT. 2013. Bioconjugate techniques: Academic press.

Hober S, Nord K, and Linhult M. 2007. Protein A chromatography for antibody purification. Journal of Chromatography B 848:40-47. DOI: 10.1016/j.jchromb.2006.09.030

Hussack G, Grohs BM, Almquist KC, McLean MD, Ghosh R, and Hall JC. 2010. Purification of plant-derived antibodies through direct immobilization of affinity ligands on cellulose. Journal of agricultural and food chemistry 58:3451-3459. DOI: 10.1021/j99040657

Jha S, Agarwal S, Sanyal I, and Amla D. 2016. Single-Step Purification and Characterization of A Recombinant Serine Proteinase Inhibitor from Transgenic Plants. Applied biochemistry and biotechnology 179:220-236. DOI: 10.1007/s12010-016-1989-8

Kang YJ, Kim D-S, Myung S-C, and Ko K. 2017. Expression of a Human Prostatic Acid Phosphatase (PAP)-IgM Fc Fusion Protein in Plants Using In vitro Tissue Subculture. Frontier in Plant Science 8:274. DOI: 10.3389/fpls.2017.00274

Kim D-S, Song I, Kim J, Kim D-S, and Ko K. 2016. Plant recycling for molecular biofarming to produce recombinant anti-cancer mAb. Frontier in Plant Science 7:1037. DOI: 10.3389/fpls.2016.01037

Ko K, Ahn M-H, Song M, Choo Y-K, Kim HS, Ko K, and Joung H. 2008. Glyco-engineering of biotherapeutic proteins in plants. Molecules \& Cells 25(4):494-503

Ko K, Tekoah Y, Rudd PM, Harvey DJ, Dwek RA, Spitsin S, Hanlon CA, Rupprecht C, Dietzschold B, and Golovkin M. 2003. Function and glycosylation of plant-derived antiviral monoclonal antibody. Proceedings of the National Academy of Sciences 100:8013-8018. DOI: 10.1073/pnas.0832472100

Kubota K, Kubo T, Tanigawa T, Naito T, and Otsuka K. 2017. New platform for simple and rapid protein-based affinity reactions. Scientific reports 7:178. DOI: 10.1038/s41598-01700264-y 
335

336

337

338

339

340

341

342

343

344

345

346

347

348

349

350

351

352

353

354

355

356

357

358

359

360

361

362

363

364

365

Lim CY, Lee KJ, Oh DB, and Ko K. 2014. Effect of the developmental stage and tissue position on the expression and glycosylation of recombinant glycoprotein $\mathrm{GA} 733-\mathrm{FcK}$ in transgenic plants. Frontier in Plant Science 5:778. DOI: 10.3389/fpls.2014.00778

Lin W, Zheng X, Wang H, Yu L, Zhou X, Sun Y, Zhao S, Du Z, and Zhang K. 2017. Purification and characterization of a novel cell-penetrating carrier similar to cholera toxin chimeric protein. Protein expression and purification 129:128-134. DOI: 10.1016/j.pep.2016.03.007

Liu D, Guo H, Zheng W, Zhang N, Wang T, Wang P, and Ma X. 2016. Discovery of the cellpenetrating function of A 2 domain derived from LTA subunit of Escherichia coli heatlabile enterotoxin. Applied microbiology and biotechnology 100:5079-5088. DOI: 10.1007/s00253-016-7423-x

Liu HF, Ma J, Winter C, and Bayer R. 2010. Recovery and purification process development for monoclonal antibody production. MAbs 2: 480-499 DOI: 10.4161/mabs.2.5.12645

Liu Y, and Yu J. 2016. Oriented immobilization of proteins on solid supports for use in biosensors and biochips: a review. Microchimica Acta 183:1-19. DOI: 10.1007/s00604-015-1623-4

Lu Z, Lee K-J, Shao Y, Lee J-H, So Y, Choo Y-K, Oh D-B, Hwang K-A, Oh SH, and Han YS. 2012. Expression of GA733-Fc fusion protein as a vaccine candidate for colorectal cancer in transgenic plantsJournal of Biomedicine and Biotechnology 2012:11 DOI: $10.1155 / 2012 / 364240$

Mazzer AR, Perraud X, Halley J, O'Hara J, and Bracewell DG. 2015. Protein A chromatography increases monoclonal antibody aggregation rate during subsequent low $\mathrm{pH}$ virus inactivation hold. Journal of Chromatography A 1415:83-90. DOI: 10.1016/j.chroma.2015.08.068

Minakuchi K, Murata D, Okubo Y, Nakano Y, and Yoshida S. 2013. Remarkable alkaline stability of an engineered protein $\mathrm{A}$ as immunoglobulin affinity ligand: $\mathrm{C}$ domain having only one amino acid substitution. Protein Science 22:1230-1238. DOI: 10.1002/pro.2310

Moussavou G, Ko K, Lee J-H, and Choo Y-K. 2015. Production of monoclonal antibodies in plants for cancer immunotherapy. BioMed Research International 2015:9 DOI: $10.1155 / 2015 / 306164$

Oey M, Lohse M, Kreikemeyer B, and Bock R. 2009. Exhaustion of the chloroplast protein synthesis capacity by massive expression of a highly stable protein antibiotic. The plant 
366

367

368

journal 57:436-445. DOI: 10.1111/j.1365-313X.2008.03702.X

Oliveira CR, Tamashiro WMSC, and Bueno SMA. 2015. Evaluation of OPS-agarose pseudoaffinity adsorption IgG2a mouse monoclonal antibody. Process Biochemistry 50:22672274. DOI: 10.1016/j.procbio.2015.09.003

Park S-R, Lim C-Y, Kim D-S, and Ko K. 2015. Optimization of ammonium sulfate concentration for purification of colorectal cancer vaccine candidate recombinant protein GA733-FcK isolated from plants. Frontier in Plant Science 6:1040. DOI: 10.3389/fpls.2015.01040

Pollock J, Coffman J, Ho SV, and Farid SS. 2017. Integrated continuous bioprocessing: Economic, operational and environmental feasibility for clinical and commercial antibody manufacture. Biotechnology progress. 33:854-866. DOI: 10.1002/btpr.2492

Romanik G, Gilgenast E, Przyjazny A, and Kamiński M. 2007. Techniques of preparing plant material for chromatographic separation and analysis. Journal of biochemical and biophysical methods 70:253-261. DOI: 10.1016/j.jbbm.2006.09.012

Rosenberg Y, Sack M, Montefiori D, Forthal D, Mao L, Hernandez-Abanto S, Urban L, Landucci G, Fischer R, and Jiang X. 2013. Rapid high-level production of functional HIV broadly neutralizing monoclonal antibodies in transient plant expression systems. PLoS One 8:e58724. DOI: 10.1371/journal.pone.0058724

SADA, Eizo. 1990. Engineering aspects of bioaffinity separation. Journal of chemical engineering of Japan, 23.3: 259-269. DOI:10.1252/jcej.23.259

Saraswat M, Musante L, Ravidá A, Shortt B, Byrne B, and Holthofer H. 2013. Preparative purification of recombinant proteins: current status and future trends. BioMed Research International 2013:18 DOI: 10.1155/2013/312709

Sharma R, and Sathishkumar R. 2017. rapid Production of therapeutic Proteins using Plant System. Defence Life Science Journal 2:95-102 DOI : 10.14429/dlsj.2.11372

Sheng S, and Kong F. 2012. Separation of antigens and antibodies by immunoaffinity chromatography. Pharmaceutical biology 50:1038-1044. DOI: 10.3109/13880209.2011.653493

Song I, Kim MK, Jamal A, Hwang K-A, and Ko K. 2015. Comparison of total soluble protein in various horticultural crops and evaluation of its quantification methods. Horticulture, Environment, and Biotechnology 56:123-129. DOI: 10.1007/s13580-015-0097-y 
397

398

399

400

401

402

403

404

405

406

407

408

409

410

411

412

413

414

415

416

Tehrani Najafian F, Bibi NS, Islam T, and Fernández-Lahore M. 2017. A megaporous material harbouring a peptide ligand for affinity IgG purification. Electrophoresis 38:29142921. DOI: $10.1002 /$ elps.201700198

Tschofen M, Knopp D, Hood E, and Stöger E. 2016. Plant molecular farming: much more than medicines. Annual Review of Analytical Chemistry 9:271-294. DOI: 10.1146/annurevanchem-071015-041706

Welch NG, Scoble JA, Muir BW, and Pigram PJ. 2017. Orientation and characterization of immobilized antibodies for improved immunoassays. Biointerphases 12:02D301. DOI: $10.1116 / 1.4978435$

Wilken LR, and Nikolov ZL. 2012. Recovery and purification of plant-made recombinant proteins. Biotechnology advances 30:419-433. DOI: 10.1016/j.biotechadv.2011.07.020

Zhang C, Sanders JP, Xiao TT, and Bruins ME. 2015. How does alkali aid protein extraction in green tea leaf residue: a basis for integrated biorefinery of leaves. PLoS One 10:e0133046. DOI: 10.1371/journal.pone.0133046

Zhang X, Duan Y, and Zeng X. 2017. Improved Performance of Recombinant Protein A Immobilized on Agarose Beads by Site-Specific Conjugation. ACS Omega 2:1731-1737. DOI: $10.1021 /$ acsomega.7b00362

Zucca P, Fernandez-Lafuente R, and Sanjust E. 2016. Agarose and its derivatives as supports for enzyme immobilization. Molecules 21:1577. DOI: 10.3390/molecules21111577 


\section{$417 \quad$ Figure legends}

418 Figure 1. Generation of transgenic Arabidopsis to express anti-rabies virus mAb ${ }^{\text {PSO57. }}$

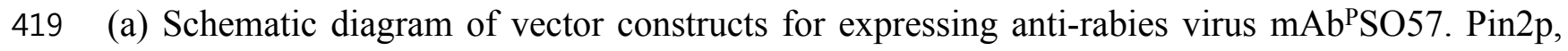
420 promoter of Pin2 gene from potato; and Ca2p, cauliflower mosaic virus 35S promoter; control 421 expression of light and heavy chains, respectively. K, KDEL, the 3' endoplasmic reticulum (ER) 422 retention motif; A, an alfalfa mosaic virus untranslated leader sequence of RNA4; Pin2T, 423 terminator of Pin2 gene from potato; NOST, terminator of nopaline synthase (NOS) gene. (b) 424 Selection and screening of $\mathrm{T}_{1}$ transformants. Shoots that survived under kanamycin antibiotic 425 selection were transferred to a soil pot and placed in a growth chamber under $16 \mathrm{~h} \mathrm{light} / 8 \mathrm{~h}$ dark 426 cycle at $23^{\circ} \mathrm{C}$ (left). PCR and western blot analyses of $\mathrm{T}_{1}$ generation plants to confirm heavy chain 427 (HC) and light chain (LC) gene existence and expression level. The genomic DNA fragments were 428 extracted from fresh leaf tissue, amplified, and separated on a 1\% agarose gel using 429 electrophoresis. HC (50 kDa) and LC (25 kDa) were detected with HRP-conjugated goat anti430 human IgG Fc- or IgG F(ab') ${ }_{2}$-specific antibodies, respectively. Lane 1-8, $\mathrm{T}_{1}$ transformants

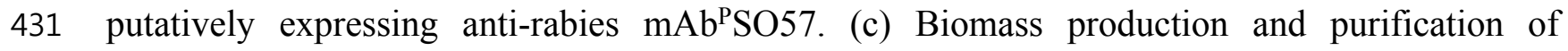
432 transgenic Arabidopsis expressing $\mathrm{mAb}$ PSO57. Seeds were sown in a greenhouse, under 433 conditions of $24^{\circ} \mathrm{C}, 30 \%$ humidity, and $16 \mathrm{~h}$ light $/ 8 \mathrm{~h}$ dark cycle. 
435 Figure 2. Purification of anti-rabies $\mathbf{m A b}{ }^{\text {PSO57 }}$ with different resins. Total soluble protein 436 (TSP) extraction and purification process to purify mAbPSO57 with four differently coupled 437 resins, and a control resin. The purification process was modified from Park et al [11]. Epoxy438 activated agarose beads were coupled to protein $\mathrm{A}$ under the $\mathrm{pH}$ conditions of 8.5, 9.5, 10.5, and $43911.5(8.5 \mathrm{R}, 9.5 \mathrm{R}, 10.5 \mathrm{R}$, and 11.5R, respectively). Commercial protein A resin (GR) (GE 440 Healthcare, Uppsala, Sweden) was used as a positive control. 
441 Figure 3. Schematic diagram of pH-dependent covalent bonding of epoxy-activated agarose 442 bead and different functional groups of recombinant protein $\mathbf{A}$. The epoxy group on agarose 443 beads can react with sulfhydryl, amines, or hydroxyl groups of protein A according to $\mathrm{pH}$ 444 conditions. Sulfhydryl groups are highly reactive with epoxide in the range of pH 7.5-8.5 (left), 445 amine nucleophiles react at moderate alkaline $\mathrm{pH}$ (middle) $\mathrm{u}$, and hydroxyl groups require high $\mathrm{pH}$ 446 conditions in the rage of $\mathrm{pH} 11-12$ (right). 
447 Figure 4. SDS-PAGE analysis of eluted F1-F7 fractions of purified samples obtained from 448 transgenic Arabidopsis expressing mAbPSO57 in reducing condition. Lane 1-7, eluted 449 fractions of the purification F1-F7, respectively; Lane 9, flow through; HC, heavy chain of mAb ${ }^{\mathrm{P}}$; $450 \mathrm{LC}$, light chain of $\mathrm{mAb} \mathrm{b}^{\mathrm{P}}$. Epoxy-activated agarose beads were coupled to protein $\mathrm{A}$ under the $\mathrm{pH}$ 451 conditions of $8.5,9.5,10.5$, and $11.5(8.5 \mathrm{R}, 9.5 \mathrm{R}, 10.5 \mathrm{R}$, and $11.5 \mathrm{R}$, respectively). Commercial 452 protein A resin (GR) (GE Healthcare, Uppsala, Sweden) was used as a positive control. 
453 Figure 5. Quantification analysis of eluted fraction F1-F7 of purified mAbPO57 using 454 Epoch spectrometer. The vertical axis values $(\mu \mathrm{g} / \mathrm{ml})$ represent the mean value of four-time triple 455 measurement per each case. Diamond, positive control resin (GE) (GE Healthcare, Uppsala, 456 Sweden); Square, resins under $\mathrm{pH} 8.5$ condition (8.5R); Triangle, resins under $\mathrm{pH} 9.5$ condition 457 (9.5R); Circle, resins under $\mathrm{pH} 10.5$ condition (10.5R), and Cross, resins under $\mathrm{pH} 11.5$ 458 condition(11.5R), respectively. 
459 Figure 6. Comparison of virus-neutralizing activity of $\mathbf{m A b}{ }^{\mathrm{PSO}} \mathrm{O57}$ purified from resins 460 differently coupled to protein A under pH 8.5, 9.5, 10.5, and 11.5 conditions (8.5R, 9.5R, $461 \mathbf{1 0 . 5 R}$, and 11.5R, respectively) against target rabies viruses. The values (IU/ml) represent the 462 mean value of duplicate measurements. Commercial protein A resin (GR) (GE Healthcare, 463 Uppsala, Sweden) was used as a positive control.

464 


\section{Figure 1}

Generation of transgenic Arabidopsis to express anti-rabies virus mAbPSO57.

(A) Schematic diagram of vector constructs for expressing anti-rabies virus $m A b^{\mathrm{P} S 057 . ~ P i n 2 p}$, promoter of Pin2 gene from potato; and Ca2p, cauliflower mosaic virus $35 \mathrm{~S}$ promoter; control expression of light and heavy chains, respectively. K, KDEL, the $3^{\prime}$ endoplasmic reticulum (ER) retention motif; A, an alfalfa mosaic virus untranslated leader sequence of RNA4; Pin2T, terminator of Pin2 gene from potato; NOST, terminator of nopaline synthase (NOS) gene. (B) Selection and screening of $T_{1}$ transformants. Shoots that survived under kanamycin antibiotic selection were transferred to a soil pot and placed in a growth chamber under $16 \mathrm{~h}$ light/8 $\mathrm{h}$ dark cycle at $23^{\circ} \mathrm{C}$ (left). PCR and western blot analyses of $\mathrm{T}_{1}$ generation plants to confirm heavy chain (HC) and light chain (LC) gene existence and expression level. The genomic DNA fragments were extracted from fresh leaf tissue, amplified, and separated on a $1 \%$ agarose gel using electrophoresis. $\mathrm{HC}(50 \mathrm{kDa})$ and LC (25 kDa) were detected with HRP-conjugated goat anti-human IgG Fc- or $\lg G \mathrm{~F}\left(\mathrm{ab}^{\prime}\right)_{2}$-specific antibodies, respectively. Lane 1-8, $\mathrm{T}_{1}$ transformants putatively expressing anti-rabies $\mathrm{mAb}$ PO57. (C) Biomass production and purification of transgenic Arabidopsis expressing $\mathrm{mAb}{ }^{\mathrm{P} S 057}$. Seeds were sown in a greenhouse, under conditions of $24^{\circ} \mathrm{C}, 30 \%$ humidity, and $16 \mathrm{~h}$ light/ $8 \mathrm{~h}$ dark cycle. 
A)

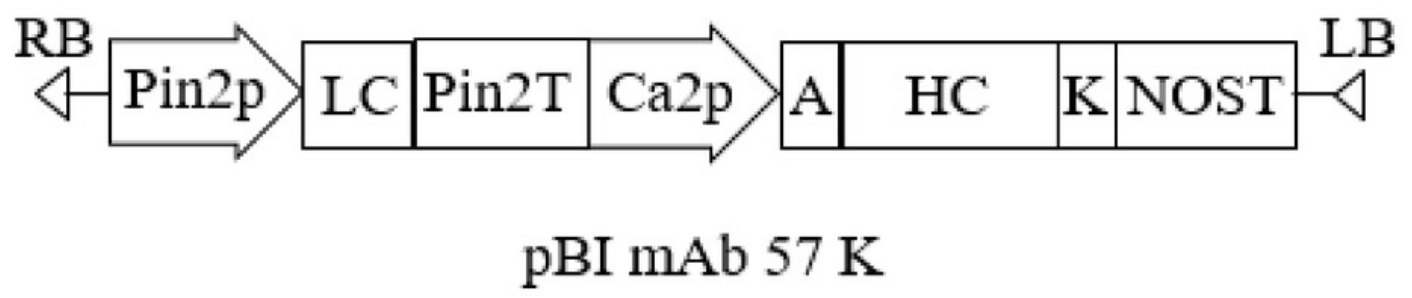

B)

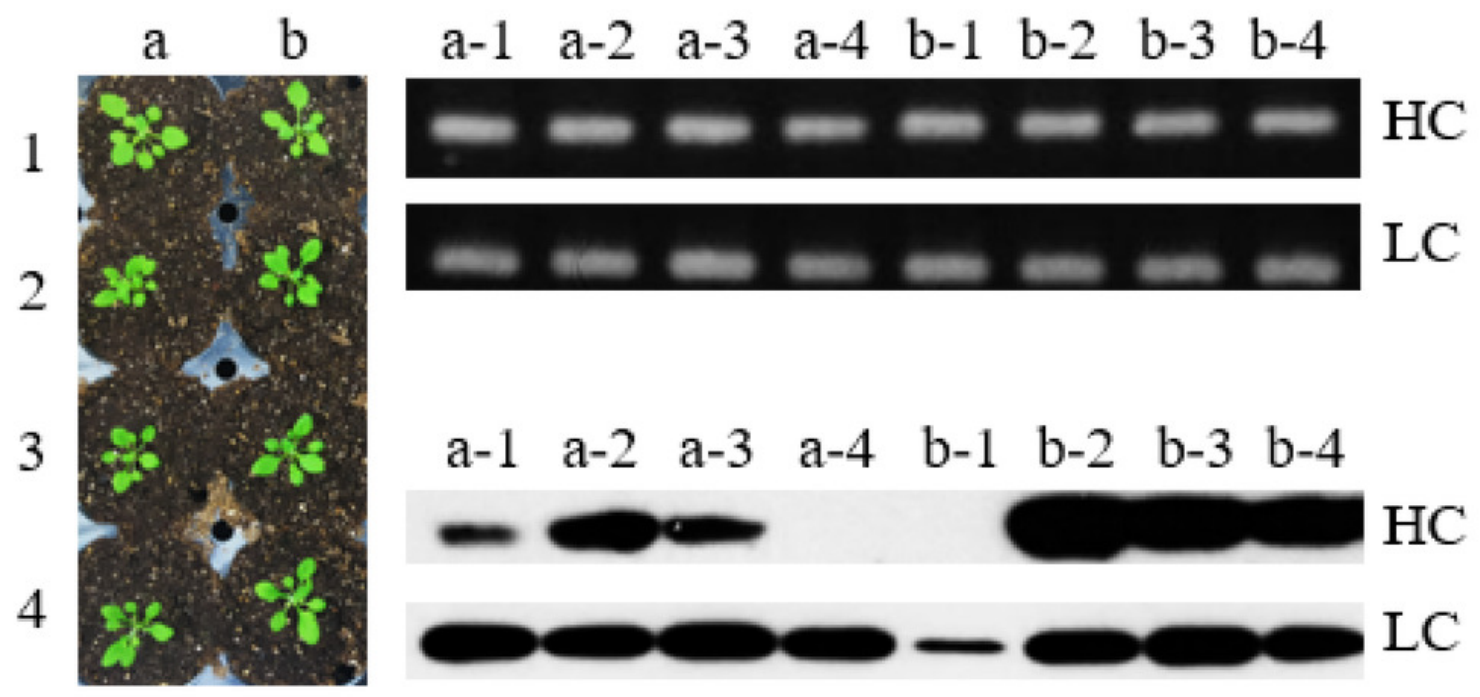

C)

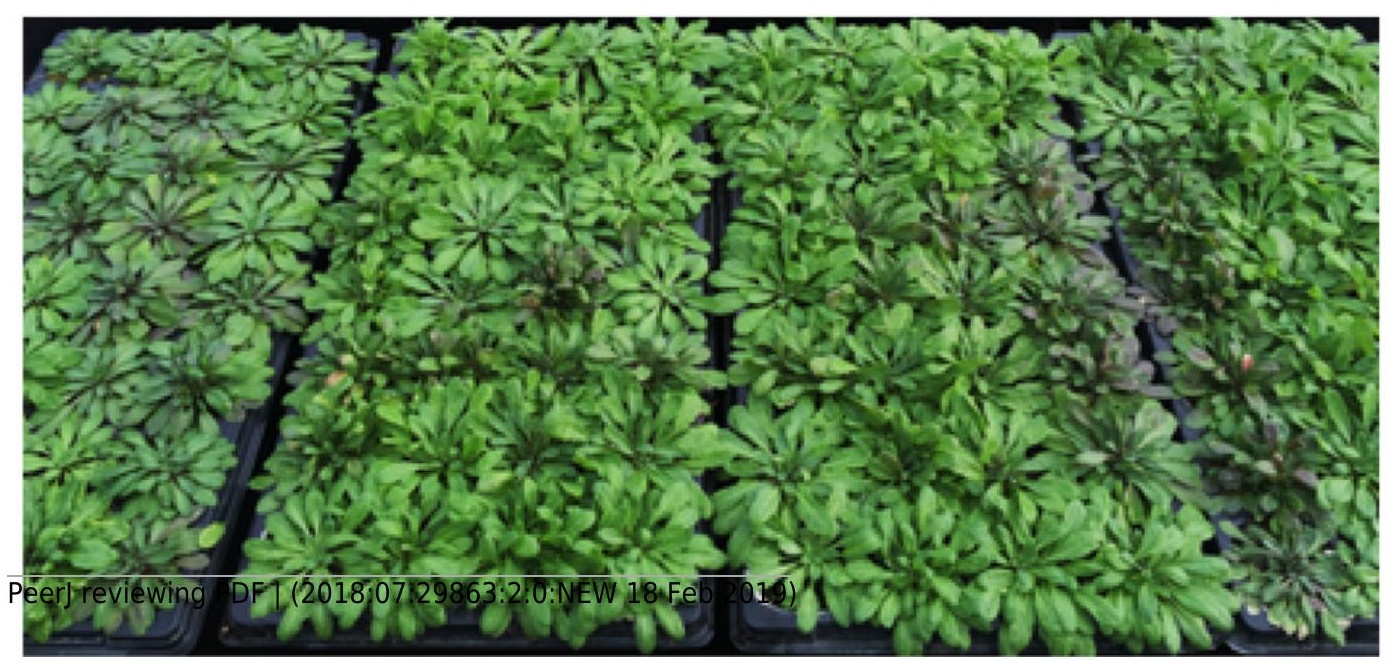




\section{Figure 2}

Purification of anti-rabies $\mathrm{mAb}$ PSO57 with different resins.

Total soluble protein (TSP) extraction and purification process to purify mAbPSO57 with four differently coupled resins, and a control resin. The purification process was modified from Park et al [11]. Epoxy-activated agarose beads were coupled to protein $\mathrm{A}$ under the $\mathrm{pH}$ conditions of $8.5,9.5,10.5$, and $11.5(8.5 \mathrm{R}, 9.5 \mathrm{R}, 10.5 \mathrm{R}$, and $11.5 \mathrm{R}$, respectively). Commercial protein A resin (GR) (GE Healthcare, Uppsala, Sweden) was used as a positive control.

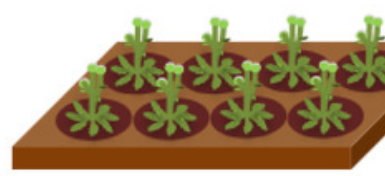

Harvesting (300g)

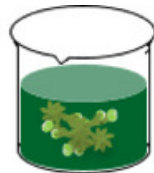

(1) Grinding

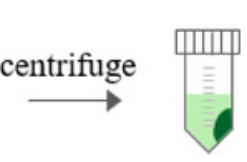

(2) Removing debris

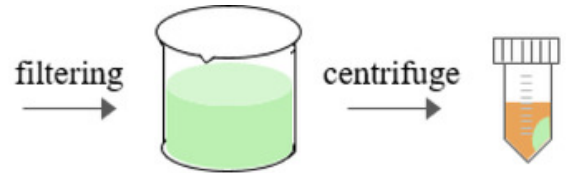

(3) $\mathrm{pH}$ adjustment

(4) Removing chloroplast

(5) Total soluble protein (TSP) precipitation

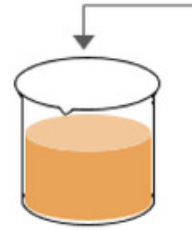

TSP extraction solution $(300 \mathrm{ml})$

Dividing solution $(60 \mathrm{ml})$
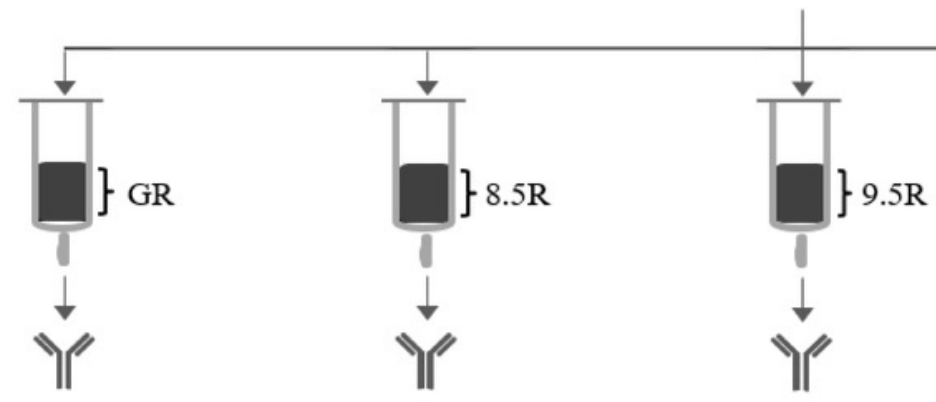

Purified $\mathrm{mAb}^{\mathrm{P}} \mathrm{SO} 57$
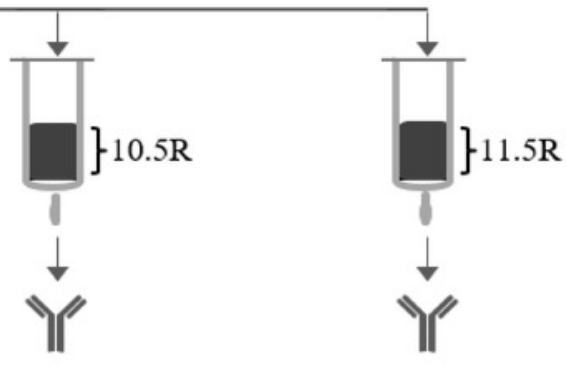
Figure 3

Schematic diagram of $\mathrm{pH}$-dependent covalent bonding of epoxy-activated agarose bead and different functional groups of recombinant protein $A$.

The epoxy group on agarose beads can react with sulfhydryl, amines, or hydroxyl groups of protein A according to $\mathrm{pH}$ conditions. Sulfhydryl groups are highly reactive with epoxide in the range of $\mathrm{pH} 7.5-8.5(\mathrm{~A})$, amine nucleophiles react at moderate alkaline $\mathrm{pH}(\mathrm{B}) \mathrm{u}$, and hydroxyl groups require high $\mathrm{pH}$ conditions in the rage of $\mathrm{pH}$ 11-12 (C).

A

pH 7.5 $\sim 8.5$

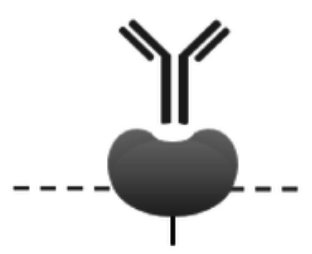

(-)
B

pH 9.5 10.5
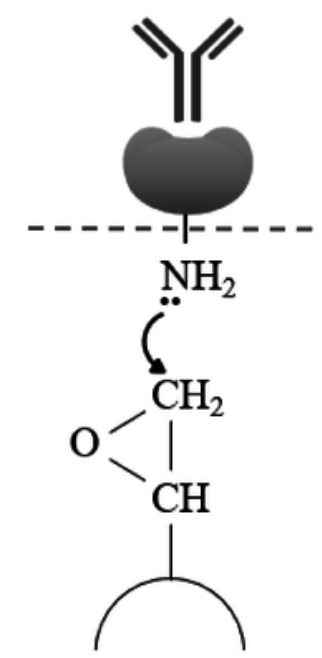

C

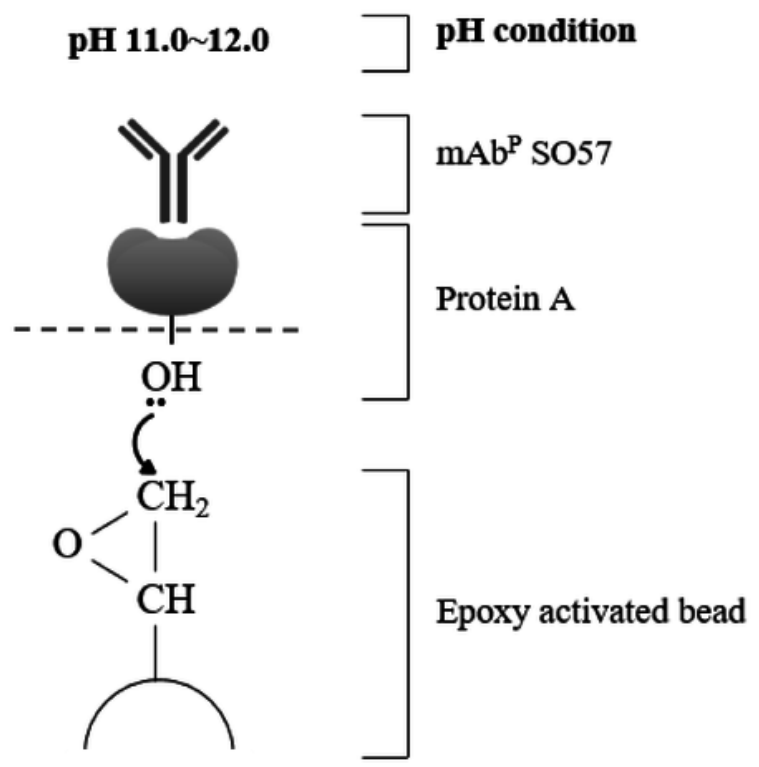




\section{Figure 4}

SDS-PAGE analysis of eluted F1-F7 fractions of purified samples obtained from transgenic Arabidopsis expressing $\mathrm{mAb}{ }^{\mathrm{P} S O} \mathrm{~S} 7$ in reducing condition.

Lane 1-7, eluted fractions of the purification F1-F7, respectively; Lane 9, flow through; HC, heavy chain of $m A b^{p}$; $L C$, light chain of $m A b^{p}$. Epoxy-activated agarose beads were coupled to protein $\mathrm{A}$ under the $\mathrm{pH}$ conditions of 8.5, 9.5, 10.5, and 11.5 (8.5R, 9.5R, 10.5R, and 11.5R, respectively). Commercial protein A resin (GR) (GE Healthcare, Uppsala, Sweden) was used as a positive control. 


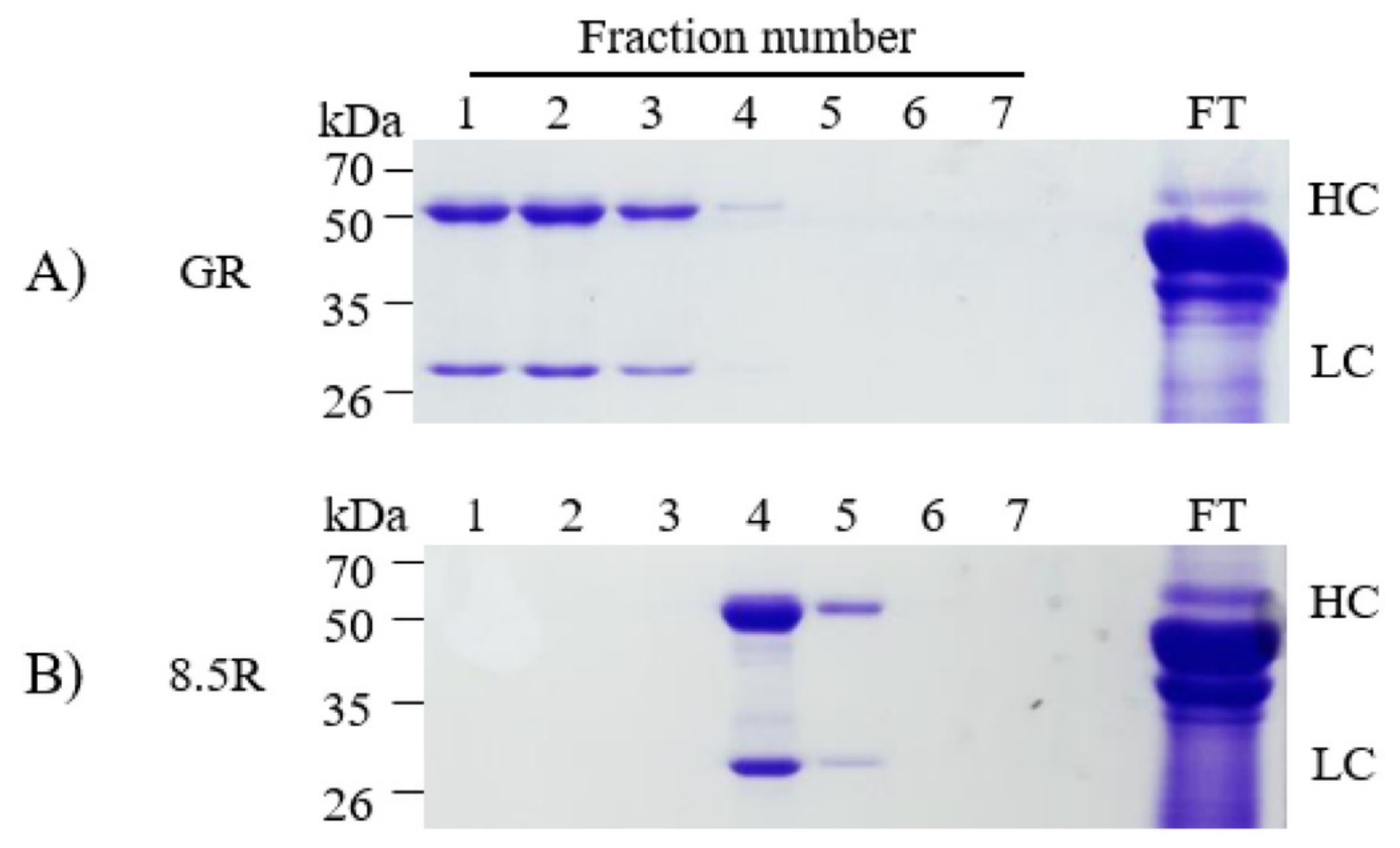

C) $9.5 \mathrm{R}$

$\mathrm{kDa}$
$70^{-}$
$50^{-}$
$35^{-}$
$26^{-}$

FT

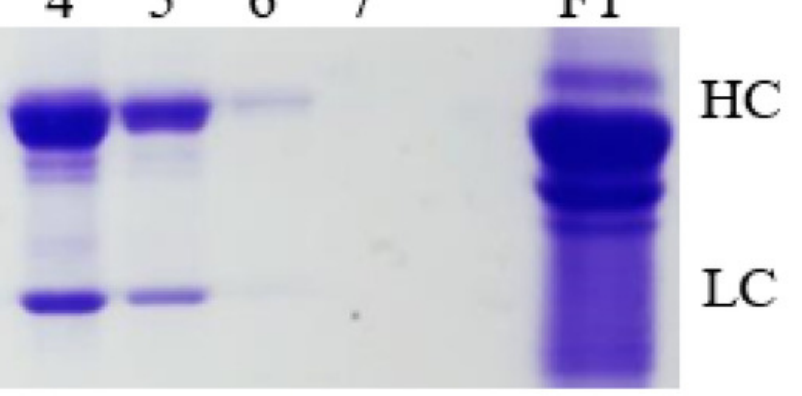

FT

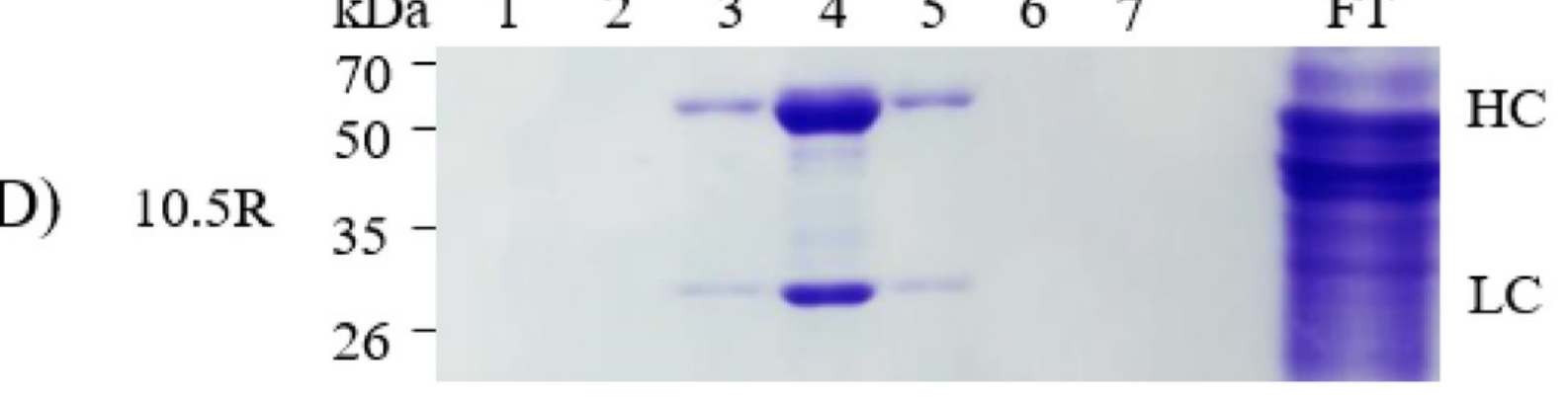

D) $10.5 \mathrm{R}$

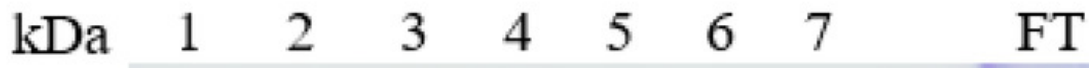
$70-$

E) $11.5 \mathrm{R}$

$50-$

$\mathrm{HC}$

LC
} 
Figure 5

Quantification analysis of eluted fraction F1-F7 of purified mAbPO57 using Epoch spectrometer.

The vertical axis values $(\mu \mathrm{g} / \mathrm{ml})$ represent the mean value of four-time measurement per each case. Diamond, positive control resin (GE) (GE Healthcare, Uppsala, Sweden); Square, resins under pH 8.5 condition (8.5R); Triangle, resins under pH 9.5 condition (9.5R); Circle, resins under $\mathrm{pH} 10.5$ condition (10.5R), and Cross, resins under $\mathrm{pH} 11.5$ condition(11.5R), respectively.

*Note: Auto Gamma Correction was used for the image. This only affects the reviewing manuscript. See original source image if needed for review.

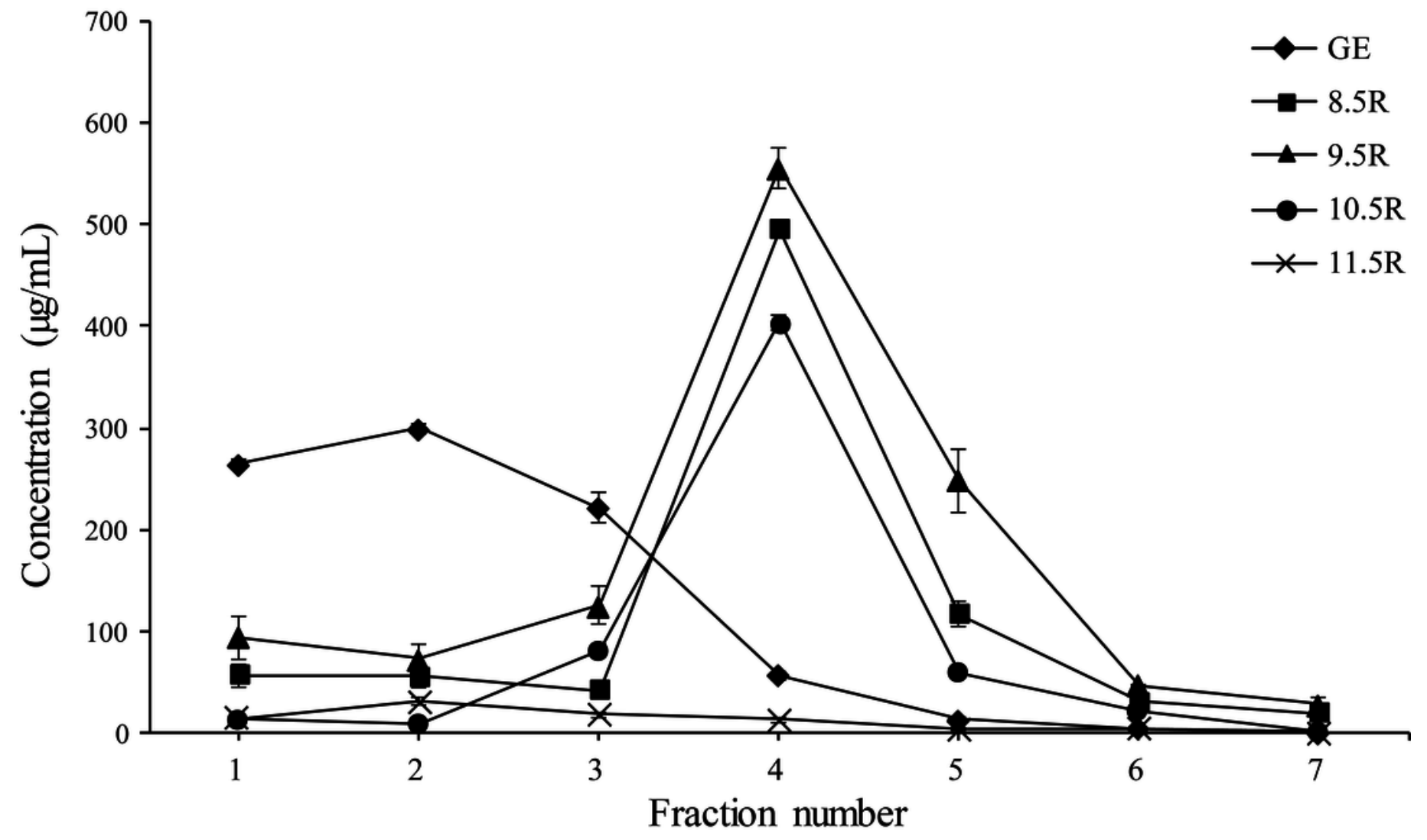




\section{Figure 6}

Comparison of virus-neutralizing activity of $\mathrm{mAb}{ }^{\mathrm{P} S O} 57$ purified from resins differently coupled to protein $A$ under $\mathrm{pH} 8.5,9.5,10.5$, and 11.5 conditions (8.5R, 9.5R, 10.5R, and $11.5 R$, respectively) against target rabies viruses.

The values $(\mathrm{IU} / \mathrm{ml})$ represent the mean value of duplicate measurements. Commercial protein A resin (GR) (GE Healthcare, Uppsala, Sweden) was used as a positive control.

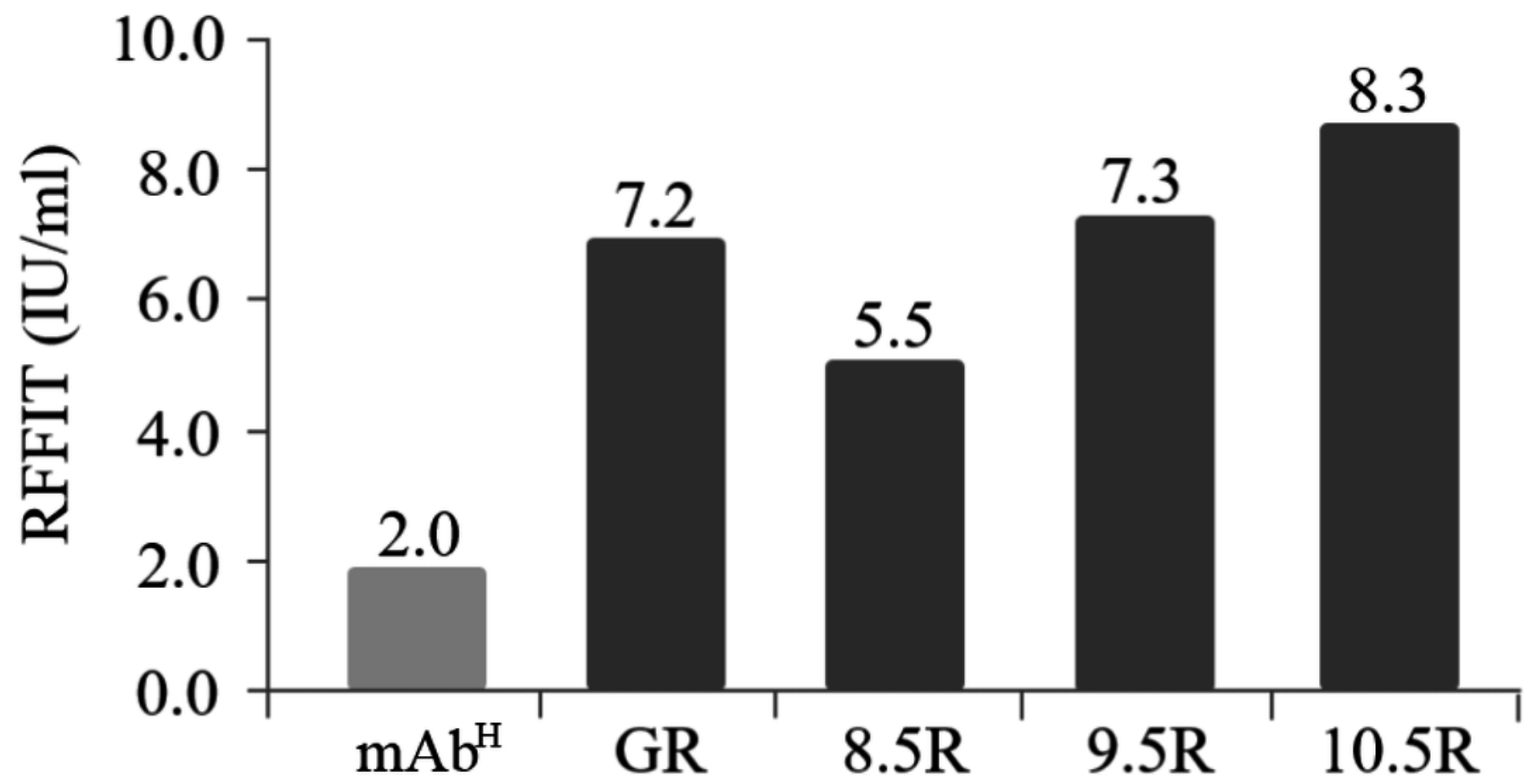

